DOI: https://doi.org/10.32839/2304-5809/2020-12-88-43

удК 342.9

Соловей Н.В.

Національний технічний університет України «Київський політехнічний інститут імені Ігоря Сікорського»

\title{
СТАНОВЛЕННЯ ТА РОЗВИТОК АДМІНІСТРАТИВНОГО ПРАВА В КРАЇНАХ ЗАХІДНОЇ ЄВРОПИ ТА УКРАЇНІ
}

\begin{abstract}
Анотація. Статтю присвячено становленню та розвитку адміністративного права в країнах Західної Європи та Україні. Проаналізовано еволюцію наукових підходів до розвитку адміністративного права, виділено кілька етапів становлення адміністративного права як фундаментальної правової науки. Проаналізовано особливості розвитку поліцейського права на території країн Західної Свропи загалом та в Україні зокрема як підгрунтя адміністративного права України в сучасному розумінні. Розглянуто об'єктивні та суб'єктивні фрактори, що вплинули на історію розвитку адміністративного права. Встановлено, що виникнення та розвиток науки адміністративного права є одним з елементів правової науки та юридичної дійсності. Визначено необхідність забезпечення гарантій захисту прав суб'єктів приватного права у їх взаємовідносинах із суб’єктами владних повноважень.
\end{abstract}

Ключові слова: камералістика, поліцейське право, адміністративне право, право управління, державне управління.

Solovei Nataliia

National Technical University of Ukraine «Igor Sikorsky Kyiv Polytechnic Institute»

\section{ESTABLISHMENT AND DEVELOPMENT OF ADMINISTRATIVE LAW IN THE TERRITORIES OF WESTERN EUROPE AND UKRAINE}

Summary. The article is devoted to the formation and development of administrative law in Western Europe and Ukraine. The evolution of scientific approaches to the development of administrative law is analyzed, several stages of formation of administrative law as a fundamental legal science are highlighted. The peculiarities of the development of the police law in the territory of the regions of Western Europe were analyzed, and in Ukraine, as a rule of the administrative law of Ukraine in a modern sense. The objective and subjective factors that influenced the history of administrative law are considered. It is established that the emergence and development of the science of administrative law is one of the elements of legal science and legal reality. The need to provide guarantees for the protection of the rights of private law entities in their relations with the subjects of power has been identified. There are usually three stages in the formation of administrative law: cameralistics (XVII-XVIII centuries), during which the foundations of administrative law - cameralistics, the second stage developed in the XVIII-XIX centuries, when administrative law acts as a police law, and the third stage - at the turn of the XIX-XX century forms its own administrative law, which includes police law as part of the industry. The main purpose of administrative law in Western Europe is to stabilize governance and stimulate social development. In Ukraine, it is a leading industry that regulates public relations in the process of public administration. The historical development of administrative law testifies to the decisive influence of European standards on the formation of scientific knowledge in this field today and understanding the purpose of administrative law in general. Perspective directions of administrative law reform in Ukraine should be based on the positive experience of Western Europe based on the concept of priority of human and civil rights and freedoms over the protection of state, collective or public interests in general, thereby ensuring democratic and effective protection of the rights, freedoms and legitimate interests of individuals and legal entities.

Keywords: cameralistics, police law, administrative law, law of management, public administration.

$\Pi$ остановка проблеми. Нині Україна знаходиться на стадії стабілізації демократичних процесів, які мають забезпечити становлення іï як правової та соціальної держави, в якій визнаеться принцип верховенства права та гарантуються усі без винятку основоположні права та свободи громадян. Частина зазначених завдань виконуються за рахунок адміністративного права та його норм. Масштабність і складність завдань та реформ, які переживає наша країна сьогодні, вимагае потужного та сучасного адміністративно-правового забезпечення.

Аналіз останній досліджень та публікацій. Сьогодні у літературі сформульовано чималу кількість визначень адміністративного права, проте вони не повною мірою охоплюють собою зміст цієё категорії. Це може пояснюватися лише складним характером адміністративного права. 3 огляду на це пропонуемо визначити основні кроки становлення та розвитку адміністративного права в країнах Західної Свропи та його вплив на розуміння адміністративного права України сьогодні.

Найбільш вагомий вклад у вивчення процесу становлення та розвитку адміністративного права, дослідженню історико-правових аспектів теорії вітчизняного адміністративного права присвятили свої праці А.Б. Авер'янов, Ю.П. Битяк, А.О. Селіванов, О.Ф. Андрійко, А.С. Васильєв, О.І. Харитонова, М. Бунге, О.М. Бандурка, А.І. Берлач, В.М. Гаращук, Є.Д. Додін, Р.А. Калюжний, Л.В. Коваль, Т.О. Коломоєць, Д.М. Лук'янець, Н.Р. Нижник, Г.О. Пономаренко, М.М. Тищенко та інші.

Виділення невирішених раніше частин загальної проблеми. В умовах демократичного розвитку адміністративного права в Україні 
активно редормуються окрему інститути галузі, з'являеться нова термінологія, впроваджуються европейські стандарти, що має визначний вплив на розуміння окремих понять адміністративного права приватними особами та їх відносини 3 суб'ектами владних повноважень, ролі та призначення адміністративного права. Проаналізовані історичні процеси становлення адміністративного права вказують на необхідність ознайомлення із становленням та розвитком даної галузі.

Мета статті. Головною метою статті є описати становлення та розвиток адміністративного права в країнах західної Свропи та його вплив на розвиток адміністративного права незалежної України.

Виклад основного матеріалу. Наука адміністративного права пройшла складний еволюційний шлях пошуку власної методології, об'єкта та загалом розкриття феноменології адміністративного права. На формування адміністративного права справили потужний влив різні фрактори, оскільки воно великою мірою залежить від зміни політичних режимів і форм правління в країні.

Прийнято вважати, що базою для зародження адміністративного права стала наука "камералістика", яка зародилась в XVII ст. в Німеччині та Австрії. Актуальність наукового дослідження камерального права зумовлена необхідністю вивчення проблем адміністративного права в контексті розвитку регулювання суспільних відносин, що пов’язані з ефективним державним управлінням та правовим забезпеченням.

У країнах Західної Свропи термін «камералістика» (походить від латинського camera - палацова скарбниця) у період раннього Середньовіччя означало "казнохранилище», згодом це слово означало установу, яка відала королівськими доходами, королівською скарбницею. Так звані «камери» управлінські повноваження, відали збором податків, а також мали деякі поліцейські і навіть судові повноваження.

У европейських університетах викладання камералістики розпочалось 3 XVII ст., коли в Халі і Франкоруті-на-Одері (Німеччина) було засновано першу в історії кафедру камералістики. Камералістика була орієнтована на вирішення проблеми створення необхідних умов для зростання доходів казни короля (die Kammer) і являла собою своерідну різновидність німецької політики меркантилізму.

Разом $з$ тим, Хохуляк В.В. відзначае, що будучи продуктом німещької управлінської науки i практики, камералістика швидко поширювалась західноєвропейськими вченими (переважно німецькими) і в систему університетської освіти Російської імперії [1, с. 219], частиною якої були українські землі.

Поступово накопичені практичні знання в сфрері управління лише у XVII ст. офрормились у наукову дисципліну, котра виникла спочатку як наука прагматична, інструментальна зі скромними завданнями, але згодом перетворилася на політичну науку з досить об'ємним і багатогранним предметом вивчення. Виникнення камералістики пов'язано з ускладненням господарських правовідносин у країнах Західної Свропи на початку XVII ст. Тобто передумовою, причиною виникнен- ня камералістики стала необхідність урегулювання кола господарських відносин.

Камералістика передусім регулювала відносини господарського страхування (страхування транспортирних операцій, пов'язаних з морськими перевезеннями), банківською справою. Насамперед це - правове регулювання ломбардних операцій, заставного майна. 31727 р. за наказом короля Пруссії в університетах створюються кафедри під назвою «Економічні, поліцейські і камеральні науки». Необхідно зазначити, що кафедри займались саме економічним, а не юридичним напрямом навчання [2, с. 96].

Пасічник H.O., дослідивши вплив камералістики на становлення фрінансової та фінансово-правової наук в українських університетах XIX ст., вказуе, що процес становлення фрінансової та фрінансово-правової наук в університетах українських губерній Російської імперії впродовж XIX ст. був детермінований не тільки зміною соціально-економічної системи i, відповідно, домінуючих фрінансових інститутів, але й еволюцією парадигмальних підходів, відображених у працях науковців і практиків орінансової діяльності. Вчений відзначає, що метою вивчення камералістики була підготовка фрахівців для господарської або адміністративної служби. Ринкові умови господарювання зумовили нові вимоги до фінансової системи держави, правового регулювання фрінансової діяльності, органів державного управління фінансами, які, зі свого боку, для здійснення нових функцій потребували висококваліфікованих кадрів у сореpi державних, корпоративних і муніципальних фрінансів [3, с. 107-108].

Отже, можемо констатувати, що у наукових і практичних розробках камералістів мали місце спроби системного викладення основ управління i визначення окремих теоретичних основ сучасного адміністративного права, адже саме камеральна складова юридичної освіти значною мірою сприяла виділенню адміністративного, поліцейського і фрінансового права у самостійні сорери.

В. Авер'янов, Ю. Битяк, О. Луньов, А. Самойленко та деякі інші науковці констатують, що адміністративне право $є$ нащадком поліщейського права, яке, в свою чергу, виникло на основі камеральних наук або камералістики. Саме поліцейське право суттево вплинуло на розвиток та формування адміністративного права, оскільки етимологія слова "поліція» з грецького означає «місто-держава". А поліцейська діяльність з середини XVII ст. до початку XIX ст. передбачала управління всіма загальнодержавними справами.

Юрченко О., дослідивши розвиток засад поліцейського права у працях і діяльності М. Бунге, вказуе, що дослідник одним із перших у вітчизняній юридичній науці визначив поняття суб'єктів поліцейського права, до яких включив органи виконавчої влади, недержавні (муніципальні) органи земського самоврядування, а також корпоративні об'єднання [8, с. 82].

Характерними ознаками поліцейської держави Коломоєць Т.О. виділяе урядову опіку, втручання органів управління в усі сдери життедіяльності суспільства, функціонування поліцейського права для вирішення тогочасних завдань держави [4, с. 119]. 
Згодом дослідники західної Свропи розділили поліцейське право на два інститути: поліції безпеки (закони «благочиння») та поліції благоустрою (закони «благоустрою», «добробуту»). Ідеологія поліції безпеки полягала в охороні громадського порядку у державі, життя та безпеки громадян (наближене до сучасного розуміння «поліції), а діяльність поліції добробуту полягала в складній системі адміністративних заходів, спрямованих на контроль державних та приватних господарств, що стало витоком для виокремлення адміністративного права в окрему самостійну галузь права в сучасному іï розумінні.

Проневич О.С., вивчивши доктринальні засади поліцейського права Німеччини та Польщі відзначае, що поліцейське право Німеччини грунтуеться на класичних засадах, сприйнятих переважною більшістю европейських країн. Сучасна німецька поліцейсько-правова доктрина формувалася упродовж тривалого часу в умовах соціальних потрясінь і перманентного пошуку балансу інтересів суспільства та окремих індивідуумів. Дискусії щодо визначення місця та ролі поліщії у системі органів публічної влади сприяли визнанню недоцільності наділення поліції виключним правом реалізації державної монополії на забезпечення внутрішньої безпеки та усвідомленню пріоритетності розвитку множини субъектів правоохоронної (поліцейської) діяльності (державних, муніципальних, недержавних). 3 іншого боку, цілком справедливо наголошувалося на універсально-соціальному характері поліції, наділеної широкими дискреційними повноваженнями [6, с. 822]. Натомість в Україні означені поняття розумілися інакше від західноевропейських підходів і були імплементовані на території України тільки з часом.

Фактичний перехід до адміністративного права (тривав протягом другої половини XIX ст.) відбувся за сприяння буржуазних революцій, коли права та свободи людини були протиставлені могутній державі.

Важливо відзначити, що до середини XIX ст. саме державне право було галуззю права, яка регламентувала діяльність органів державної влади. У своїх наукових творах видатні західноевропейські мислителі та державознавці-Монтеск'е, Гоббс, Гуго Гроцій, розглядаючи проблеми державного устрою, невіддільно торкалися проблем державного управління. Однак, у середині XIX ст. відомий німецько-австрійський правознавець Лоренц фон Штейн переносить «державне управління» зі сфери державного права у нову галузь - «право управління». Слід відзначити, що відокремлення «державного управління» від державного права відбувається поступово, фактично протягом другої половини XIX ст. $[10$, с. 16]. При цьому відокремлюеться тільки та частина державного права, яка регулювала діяльність адміністрації.

Термін «адміністративне право» ввели у науковий обіг фрранцузькі вчені. Цьому терміну, який успішно конкурував із терміном "право управління», були притаманні ознаки родового поняття. Отже, саме термін «адміністративне право» міг об'єднати в єдине ціле дві частини адміністративно-правової діяльності - управлінську та поліцейську. Таким чином, з ускладненням підзаконної діяльності виконавчої влади, починае формуватися «право управління», або адміністративне право, яке поступово робить поліцейське право своєю автономною складовою. Проте зв'язок цих двох частин адміністративного права, незважаючи на автономний характер кожної, $е$ органічним: державно-правові відносини регламентуе право управління, а поліцейське право - їх особливий різновид, відносини у сфері громадського порядку. Отже, адміністративно-правова дійсність не монотеїстична, а дуалістична: вона одночасно існуе у сфері державного управління та у сdері громадського порядку. Тож від інших галузей права, адміністративне право мае складну історію становлення і розвитку. Загалом в еволюції адміністративного права можна виділити три етапи його становлення та розвитку: перший (XVII-XVIII століття), протягом якого формуються підвалини адміністративного права - камералістика, другий етап розвивався у XVIII-XIX століттях, коли адміністративне право виступае як поліцейське право, та третій етап - на межі XIX-XX століть формуе власне адміністративне право. На жаль, у сучасній науковій літературі мало уваги приділяеться вивченню таких складних теоретичних питань, як, наприклад, поліцейське право [7, с. 90], яке існуе і сьогодні в сучасному адміністративному праві, хоча трансформувалось у вузьку його підгалузь та виконуе виключно захисну та контролюючу функції.

На західноукраїнських землях відбувалися аналогічні процеси, хоча на їх правотворчий процес більший вплив справила Австро-Угорська імперія. Серед найважливіших актів законодавства, дія яких поширювалась і на українські землі, варто назвати декрет Марії-Терезії про регламентацію мануфактурного виробництва, друга частина XVII ст., патенти про розмір панщини і оброку, указ Йосипа II про обмеження місцевого провінційного самоврядування, закон «Про урядово-виконавчу владу». Загалом законодавство Австро-Угорської імперії можна охарактеризувати як реакційне та вкрай консервативне. Імперія до останніх днів свого існування залишалася «поліцейською державою». Однак революційні події змусили владу Австро-Угорщини запровадити елементи парламентаризму та конститущіоналізму [5, с. 26-27].

$\mathrm{У}$ країнах колишнього Радянського Союзу й соціалістичного табору для адміністративного права характерні особливості, які принципово відрізняли його від західних країн: моноідеологічна комуністична основа; чітке іерархічне підпорядкування; командно-адміністративний стиль; завеликі розміри і неефективність; невиправдано великі витрати на утримання державного апарату, суворий державний контроль за діяльністю громадських організацій, обмеження щодо практичного волевиявлення фрізичних осіб тощо.

У період домінування марксистсько-ленінських ідей на території України та інших радянських республік поняття «поліція», «поліцейська діяльність» ототожнювались із діяльністю та структурою, покликаною забезпечувати інтереси тих, хто «пригнічував робітничо-селянський клас». Виключно з ідеологічних та револющійних причин ці терміни були замінені на поняття «міліція» та «адміністративна діяльність» тощо [9]. 
Слід підкреслити, що саме за допомогою визнання поліцейського права складовою частиною адміністративного права на більш якісному рівні можна гарантувати внутрішню безпеку держави в цілому; врегулювати суспільні відносини у сфрері державного управління правоохоронною діяльністю; визначити структуру та повноваження органів державної влади та місцевого самоврядування, наділених поліцейськими фрункціями тощо.

Подальший розвиток науки адміністративного права, що є правовою основою діяльності органів внутрішніх справ України, відбуваеться без відриву від реальних потреб суспільства та держави щодо якісної охорони громадського порядку, забезпечення громадської безпеки, запобігання та боротьби зі злочинами і правопорушеннями, охорони та захисту прав і свобод людини, адже адміністративне право - одна з галузей публічного права, яка регулюе суспільні відносини, що виникають у сфері організації, а також діяльності органів публічної адміністрації, спрямованої на забезпечення та захист прав і свобод громадян.

Сьогодні переважна більшість країн світу визнають адміністративне право однією 3 основних правових галузей. Однак поняття, цілі і завдання ціеї галузі в різних країнах тлумачаться порізному. В країнах Західної Свропи цілями адміністративного права, з одного боку, визнано те, що воно покликано сприяти стабілізації управління, в 3 іншого - стимулювати суспільний розвиток.

В Україні адміністративне право - це одна з провідних галузей права, яка визначае і регулюе суспільні відносини, що виникають у процесі державного управління суспільством, а саме: діяльність органів виконавчої влади, у внутрішньоорганізаційній діяльності інших державних органів, а також в процесі здійснення об'єднаннями громадян зовнішньовладних управлінських функцій.

Історія розвитку адміністративного права свідчить, що найбільш ефективна ця галузь у тому випадку, якщо іï головним завданням стае вирішення кондрліктних ситуацій як усередині адміністрації, так і між адміністрацією та громадянами.

Новітній етап розвитку української науки адміністративного права пов'язаний з проголошенням незалежності України в 1991 р. Вагомим кроком в українському адміністративному праві стало прийняття в Україні Основного закону - Конституції України, 1996 року, в якій встановлено принцип поділу державної влади на законодавчу, виконавчу і судову; конституційне розмежування прав та обов'язків між суб'ектами державного управління; зміна практики формування і функціонування виконавчої влади; нове співвідношення політичної системи і публічного управління.

Сучасний рівень розвитку управлінських відносин, завдання формування правової демокра- тичної держави, відображені у Конституції України, обумовлюють подальший розвиток інституту адміністративно-правових форм управління, тобто необхідність наукових досліджень щодо подальшого розвитку адміністративного права.

На нашу думку, варто погодитись із позищіею В.Б. Авер'янова, який в забезпеченні демократичного режиму взаємовідносин громадян із органами виконавчої влади вбачає регламентацію основних форм і напрямків діяльності цих органів на основі непорушності конституційних прав і свобод людини і громадянина. Науковець наголошуе на тому, що основними рисами адміністративного права демократичного суспільства мають стати не «управлінська» та "каральна» функції, а «правозабезпечувальна» (пов'язана із забезпеченням реалізації прав і свобод людини) та «правозахисна» (пов'язана із захистом порушених прав) [11].

Висновки та пропозиції. Загалом виникнення та розвиток науки адміністративного права $є$ одним з елементів правової науки та юридичної дійсності. Відповідно до змін історичних типів держави, її політичної системи та економічних відносин відбувається еволюція галузі адміністративного права, яка супроводжуеться формуванням відповідної галузі наукових знань.

З аналізу європейського та вітчизняного досвіду вбачається, що, сучасна галузь адміністративного права України увібрала в себе кращі надбання вітчизняної та світової адміністративно-правової думки, вона виходить 3 концепції пріоритету прав та свобод людини і громадянина перед охороною державних, колективних чи в цілому суспільних інтересів, тим самим забезпечуе демократичний та ефективний захист прав, свобод і законних інтересів фізичних та юридичних осіб.

Перспективні напрями реформування адміністративного права в Україні мають грунтуватися на позитивному досвіді европейського регулювання. 3 урахуванням якого передусім прийнятними мають бути принципи европейського адміністративного регулювання, а вже потім, за необхідності, - узагальнені чи конкретні приписи та інститути.

Тож, можемо зробити висновок, що сьогодні українським вченим варто ще більше уваги звернути на формування завдань по забезпеченню реалізації та захисту прав суб'єктів приватного права, їх свобод та інтересів у взаємовідносинах із органами публічної влади (публічними адміністраціями та органами місцевого самоврядування). Саме такий підхід, на нашу думку, забезпечить укоріненню в юридичний науці та свідомості громадян европейських цінностей, підвищить довіру українців до органів публічного управління та наблизить українську адміністративно-правову систему до моделей, сформованих у сучасних прогресивних демократичних країнах світу.

\section{Список літератури:}

1. Хохуляк В.В. Камералістика та їі вплив на становлення вітчизняної науки фінансового права ХІХ століття. Науковий вісник Міжнародного гуманітарного університету. Юриспрудениія. 2013. № 6-1(1). С. $218-221$.

2. Панасюк Р.П. Камералістика в системі регулювання господарських правовідносин. Часопис Київського університету права. 2017. № 1. С. 95-98.

3. Пасічник Н.О. Вплив камералістики на становлення фінансової та фрінансово-правової наук в українських університетах XIX ст. Гуржї̈вські історичні читання. 2014. № 7. С. 107-110.

4. Коломоєць Т.О., Колпаков В.К. Вступ до навчального курсу «Адміністративне право України» : навч. лекція. Київ : Ін Юре, 2014. 237 с. 
5. Панасюк Р.П. Розвиток камерального права в Україні (теоретико-методологічний аспект). Судова апеляція. 2017. № 1. C. 21-27.

6. Проневич О.С. Доктринальні засади поліцейського права Німеччини та Польщі. Форул права. 2011 . № 1. C. $822-828$.

7. Фомін Ю.В. Поліцейське право та поліцейське законодавство як правова основа діяльності органів внутрішніх справ. Право і Безпека. 2011. № 4. С. 90-95.

8. Юрченко О. Розвиток засад поліцейського права у працях і діяльності Миколи Бунге. Вісник Акаделії управління МВС. 2010. № 2(14). С. 74-82.

9. Когут Я.М. Щодо використання окремих юридичних термінів у нормах поліцейського права. Науковий вісник Львівського державного університету внутрішніх справ. Серія юридична. 2016. № 1. С. 198-206.

10. Класичний френомен адміністративного права зарубіжних країн (Росія). Під ред. Заросило В.О. Київ : МП Леся, 2015. 120 с.

11. Авер'янов В.Б. Нові риси предмета українського адміністративного права. Персонал. $2005 . \quad$ № 4. URL: www.personal.in.ua

\section{References:}

1. Hohuliak V.V. (2013) Kameralistyka ta yiyi vplyv na stanovlennya vitchyznyanoyi nauky finansovoho prava XIX stolittya [Cameralistics and its influence on the formation of the domestic science of financial law of the XIX century]. Naukovyy visnyk Mizhnarodnoho humanitarnoho universytetu. Yurysprudentsiya, no. 6-1(1), pp. 218-221.

2. Panasiyk R.P. (2017) Kameralistyka v systemi rehulyuvannya hospodarskykh pravovidnosyn [Cameralistics in the system of regulation of economic relations]. Chasopys Kyyivskoho universytetu prava, no. 1, pp. 95-98.

3. Pasichnyk N.O. (2014) Vplyv kameralistyky na stanovlennya finansovoyi ta finansovo-pravovoyi nauk v ukrayinskykh universytetakh XIX st. [The influence of chamberlain on the formation of financial and financial law in Ukrainian universities of the XIX century]. Hurzhiyivski istorychni chytannya, no. 7, pp. 107-110.

4. Kolomoyets T.O., Kolpakov V.K. (2014) Vstup do navchalnoho kursu "Administratyvne pravo Ukrayiny» [Introduction to the training course "Administrative Law of Ukraine»]: navch. lektsiya. Kyiv: In Yure, $237 \mathrm{p}$.

5. Panasyuk R.P. (2017) Rozvytok kameralnoho prava v Ukrayini (teoretyko-metodolohichnyy aspekt) [Development of commercial law in Ukraine (theoretical and methodological aspect)]. Sudova apelyatsiya, no. 1, pp. 21-27.

6. Pronevych O.S. (2011) Doktrynalni zasady politseyskoho prava Nimechchyny ta Polshchi [Doctrinal principles of police law in Germany and Poland]. Forum prava, no. 1, pp. 822-828.

7. Fomin Yu.V. (2011) Politseyske pravo ta politseyske zakonodavstvo yak pravova osnova diyalnosti orhaniv vnutrishnikh sprav [Police law and police legislation as a legal basis for the activities of internal affairs bodies]. Pravo i Bezpeka, no. 4, pp. 90-95.

8. Yurchenko O. (2010) Rozvytok zasad politseyskoho prava u pratsyakh i diyalnosti Mykoly Bunhe [Development of the principles of police law in the works and activities of Nikolai Bunge]. Visnyk Akademiyi upravlinnya MVS, no. 2(14), pp. 74-82.

9. Kohut Ya.M. (2016) Shchodo vykorystannya okremykh yurydychnykh terminiv u normakh politseyskoho prava [On the use of certain legal terms in the rules of police law]. Naukovyy visnyk Lvivskoho derzhavnoho universytetu vnutrishnikh sprav. seriya yurydychna, no. 1, pp. 198-206.

10. Klasychnyy fenomen administratyvnoho prava zarubizhnykh krayin (Rosiya) [The classic phenomenon of administrative law of foreign countries (Russia)]. Pid red. Zarosylo V.O. Kyiv: MP Lesya, 2015. 120 p.

11. Aver'yanov V.B. Novi rysy predmeta ukrayinskoho administratyvnoho prava [New features of the subject of Ukrainian administrative law]. Personal, no. 4. URL: www.personal.in.ua 